SEARCHING

FOR A

DIFFERENT

FUTURE 



\section{Searching for}

\section{a Different Future}

THE RISE OF A GLOBAL

MIDDLE CLASS IN

MOROCCO

SHANA COHEN

Duke University Press Durham/London/2004 
(C) 2004 Duke University Press

All rights reserved

Printed in the United States of America on acid-free paper $\infty$

Typeset in Carter and Cone Galliard by Keystone Typesetting, Inc.

Library of Congress Cataloging-in-Publication Data

appear on the last printed page of this book. 